九州大学学術情報リポジトリ

Kyushu University Institutional Repository

Discrete-Event Simulation and Optimization of Spare Parts Inventory and Preventive Maintenance Integration Model Considering Cooling Down and Machine Dismantling Time Factor

Aliunir, Fachransjah

Department of Industrial Engineering, University of Indonesia

Teuku Yuri M. Zagloel

Department of Industrial Engineering, University of Indonesia

Ardi, Romadhani

Department of Industrial Engineering, University of Indonesia

https://doi.org/10.5109/2740949

出版情報: Evergreen. 7 (1)，pp.79-85，2020-03. 九州大学グリーンテクノロジー研究教育センター バージョン：

権利関係 : 


\title{
Discrete-Event Simulation and Optimization of Spare Parts Inventory and Preventive Maintenance Integration Model Considering Cooling Down and Machine Dismantling Time Factor
}

\author{
Fachransjah Aliunir*, Teuku Yuri M. Zagloel, and Romadhani Ardi \\ Department of Industrial Engineering, University of Indonesia, Kampus Baru UI Depok, Depok, Indonesia \\ *Fachransjah Aliunir: \\ E-mail: fachransjah@gmail.com; fachransjah.aliunir@ui.ac.id
}

(Received October 31, 2019; Revised December 16, 2019; accepted February 24, 2020).

\begin{abstract}
The time for cooling down and dismantling happens very fast so that spare parts have to be already available prior to the shutdown to avoid excessive downtime due to spare parts unavailability. This condition is common for most engines including machines in manufacturing plants, airplanes engines, ship engines, automobile engines, or heavy equipment in mining. However, this condition does not apply for gas turbines. For gas turbines, cooling down and dismantling are taking a few days and even more than 1 week. This distinctive characteristic has not been studied before. So, an integration model of spare parts inventory and preventive maintenance is proposed. The time factor of engine cooling down and dismantling will be taken into account by this proposed model. Spare parts will arrive after cooling down and dismantling period is finished using just-in-time method. The basic and proposed model are based on the case study from a power generation company in Indonesia. Discrete-event simulations (DES) are carried out using the company's historical data. The results of the DES simulation and data processing with formulas and commercial data are optimized by linear programming methods and response surface methodology (RSM). By incorporating the stochastic characteristic generated by the variations in the duration of cooling down \& dismantling, the duration of assembling, and the duration of parts delivery, the application of the proposed model can reduce the duration of spare part inventory in the warehouse which will result to lower storage cost so that it can lead to an increase in the company's profit.
\end{abstract}

Keywords: integration, model, spare, parts, maintenance, discrete-event, simulation, cooling down, dismantling

\section{Introduction}

The development of economics is one of the main objectives of modern society and to achieve it an enormous amount of manufactured goods has been produced and consumed ${ }^{1)}$, including spare parts for industrialization. Spare parts consume $2.5 \%$ of the machinery purchase price annually ${ }^{2)}$ and spare parts inventories are essential for maintenance and making sure the industrial plants to be operational ${ }^{3)}$. So, spare parts inventory is very important for facility operations.

It is quite obvious that maintenance and spare parts inventory are interrelated and have to be analyzed simultaneously ${ }^{4}$. Eventhough maintenance managers are familiar with the significance of spare parts inventory management, still, high inventory and high storage cost are still two of the biggest issues in many companies ${ }^{5}$. Time to order, order quantity, and lead time should be planned carefully to minimize storage costs and simultaneously to avoid stock-out ${ }^{6}$. The cooling down and dismantling time of the engine has never been considered before. Maintenance activities are viewed in a very general manner and are not split into steps or phases. Maintenance activity is planned to use spare parts immediately so that the parts must be already available in an exact amount prior to or exactly at the start of the maintenance activity, thus causing a certain level of inventory has to be maintained at a certain period of time. And this situation also applies in the paper that proposes the just-in-time method.

The time for cooling down and dismantling happens very fast so that spare parts have to be already available prior to the shutdown to avoid excessive downtime due to spare parts unavailability. This condition is common for most engines including machines in manufacturing plants, airplanes engines, ship engines, automobile engines, or heavy equipment in mining. For gas turbines, cooling down and dismantling are taking a few days and even more than 1 week. This distinctive characteristic has not been studied before. 


\section{Literature Review}

Maintenance and spare parts inventory joint model is becoming more and more popular lately ${ }^{7}$. Joining the two will create a far more holistic approach towards a more intensive study resulting in an accurate calculation. Every analysis and decision-making in maintenance which is not calculating spare parts inventory will not result an optimal outcome $^{7)}$. Many papers on the field of spare parts inventory and maintenance use spare parts stocking as its inventory strategy, i.e. i.e. Ilgin \& Tunali, 2007, W. Wang, 2012, Alrabghi, Tiwari, \& Alabdulkarim, 2013, Bjarnason, Taghipour, \& Banjevic, 2014, Samal \& Pratihar, 2015, Kader, Sofiene, Nidhal, \& Walid, 2015, Jiang et al., 2015, Y. Wang et al., 2016, Benmansour, Allaoui, Allaoui, Allaoui, \& Goncalves, 2016, Olde Keizer, Teunter, \& Veldman, 2017, Nguyen, Do, \& Grall, 2017, La Fata \& Passannanti, 2017, Bousdekis, Papageorgiou, Magoutas, Apostolou, \& Mentzas, 2017, Prihandoyo, Zagloel, \& Ardi, 2018, Zahedi-Hosseini, Scarf, \& Syntetos, $2018^{4,8,17-21,9-16)}$. Only 1 paper by Zahedi-Hosseini \& Scarf, 20187) which proposes the just-in-time method rather than holding stock. Various types of maintenance are used in these papers, i.e. preventive, corrective, and condition-based maintenance. Also, various kinds of methods are being used, starting from simple optimization to non-linear, mixed-integer, and stochastic optimization model $^{22)}$. All fifteen papers are using optimization as the main method of approach. And lastly, none of these papers consider the possibility to utilize the end period of cooling down and dismantling process as the point of spare parts arrival.

\section{Problem Formulation}

The maintenance strategy used in the basic model is preventive maintenance (PM) with the block replacement policy as the strategy of parts replacement. The probability of sudden engine failure that causes the engine to stop operating is not considered. Initial spare parts are provided in the storage facility since the engine starts operating and spare parts are always available to guarantee shutdowns and overhauls duration as short as possible to reduce downtime. Spare parts lead time is longer than the duration of the engine operating between preventive maintenance. We are using the Mitsubishi M701D Gas Turbine operation manual, maintenance manual, and spare parts contract for baseline data for the model. Cooling down and dismantling duration, assembling duration, spare parts lead time, PM costs, and spare parts cost data are using historical data of Grati Combined Cycle Power Plant of PT Indonesia Power in East Java, Indonesia. The data are from gas turbine number \# 1.1, \# 1.2, and \# 1.3 since March 2011 to October 2016 as tabulated in Table 1. Revenue data is obtained from power purchase agreement between PT Indonesia Power and PT PLN (Persero) as the single electricity buyer in Indonesia.
Table 1. Historical data on duration and cost of spare parts and PM of Grati Combined Cycle Power Plant Gas Turbine

\begin{tabular}{|c|c|c|c|c|c|c|}
\hline $\begin{array}{c}\text { Engine } \\
\text { Number }\end{array}$ & $\begin{array}{c}\text { PM } \\
\text { Dur. } \\
\text { (day) }\end{array}$ & $\begin{array}{c}\text { Cooling } \\
\text { Down \& } \\
\text { Dismantl. } \\
\text { Dur. } \\
\text { (day) }\end{array}$ & $\begin{array}{c}\text { Assy. } \\
\text { Dur. } \\
\text { (day) }\end{array}$ & $\begin{array}{c}\text { Spare } \\
\text { Parts } \\
\text { Lead } \\
\text { Time } \\
\text { (day) }\end{array}$ & $\begin{array}{c}\text { PM } \\
\text { Cost } \\
\text { (in } \\
\text { Million } \\
\text { IDR) }\end{array}$ & $\begin{array}{c}\text { Spare } \\
\text { Parts } \\
\text { Cost (in } \\
\text { Million } \\
\text { IDR) }\end{array}$ \\
\hline Baseline & 30 & 10 & 20 & 540 & - & - \\
\hline GT \#1.2 & 43 & 11 & 32 & 560 & - & - \\
\hline GT \#1.1 & 39 & 15 & 24 & 483 & 22,898 & 33,700 \\
\hline GT \#1.3 & 41 & 13 & 28 & 529 & 20,235 & 94,701 \\
\hline GT \#1.2 & 38 & 17 & 21 & 577 & 21,517 & 58,829 \\
\hline GT \#1.1 & 33 & 14 & 19 & 506 & 19,556 & 69,605 \\
\hline GT \#1.3 & 33 & 13 & 20 & 553 & 18,942 & 40,822 \\
\hline GT \#1.2 & 40 & 14 & 26 & 543 & 13,578 & 59,308 \\
\hline
\end{tabular}

Based on the electricity purchase agreement between PT Indonesia Power and PT PLN (Persero) as electricity single buyer in Indonesia, the value of cost and revenue of the electricity purchase are as follows:

Table 2. Data on the value of costs and revenue of the Grati Combined Cycle Power Plant Gas Turbine

\begin{tabular}{|l|r|l|l|}
\hline \multicolumn{1}{|c|}{ Parameter } & Value & \multicolumn{1}{|c|}{ Unit } & \multicolumn{1}{|c|}{$\begin{array}{c}\text { Multiplication } \\
\text { Factors }\end{array}$} \\
\hline Spare Parts Cost & 59,332 & Mil. IDR/PM & XM Frequency \\
\hline Investment Cost & 375 & Mil. IDR/day & $\begin{array}{l}\text { (Total Day of } \\
\text { Operation + Total } \\
\text { Day of PM } \\
\text { Duration) }\end{array}$ \\
\hline Storage Cost & 41 & Mil. IDR/day & $\begin{array}{l}\text { Total Day of } \\
\text { Inventory Duration }\end{array}$ \\
\hline PM Cost & 655 & Mil. IDR/day & $\begin{array}{l}\text { x Total Day of PM } \\
\text { Duration }\end{array}$ \\
\hline $\begin{array}{l}\text { Daily Operation } \\
\text { Maintenance } \\
\text { Cost }\end{array}$ & 29 & Mil. IDR/day & $\begin{array}{l}\text { (Total Day of } \\
\text { Operation + Total } \\
\text { Day of PM } \\
\text { Duration) }\end{array}$ \\
\hline Gas (fuel) Cost & 1,793 & Mil. IDR/day & $\begin{array}{l}\text { Total Day of } \\
\text { Operation }\end{array}$ \\
\hline $\begin{array}{l}\text { Lubricant \& } \\
\text { Chemical Cost }\end{array}$ & 3 & Mil. IDR/day & $\begin{array}{l}\text { x (Total Day of } \\
\text { Operation + Total } \\
\text { Day of PM } \\
\text { Duration) }\end{array}$ \\
\hline Revenue & 3,180 & Mil. IDR/day & $\begin{array}{l}\text { Total Day of } \\
\text { Operation }\end{array}$ \\
\hline
\end{tabular}

Data from Table 1 and Table 2 above will be used in all calculation after simulation. Yet, in the just-in-time implementation, there is other characteristic that are no less important that the lead time of material is always done on time with low variance ${ }^{23)}$. The data that will be used for the second scenario is the material lead time in Olckers (1998) research with adjustments using data shifting to fit the simulation model.

\section{Conceptual Model}

As illustrated in Fig. 1, the basic model will be built based on data from Table 1. Spare parts for the 1st PM are already available in the storage facility from day 1 and spare parts for the 2nd PM are ordered on day 1. Spare parts for 2nd PM are shipped faster than the baseline data for simplification, and the next orders will follow the baseline data which take 540 days from ordering to arrival. PMs are always carried out for 30 days after 360 days of operation. It is assumed that every PM follows the scope 
of major overhaul, while in reality there are 2 more types of PM for gas turbines, i.e. combustor inspection and turbine inspection which don't require any spare parts replacement. Spare parts are always available in the storage facility during the engine is in operation.

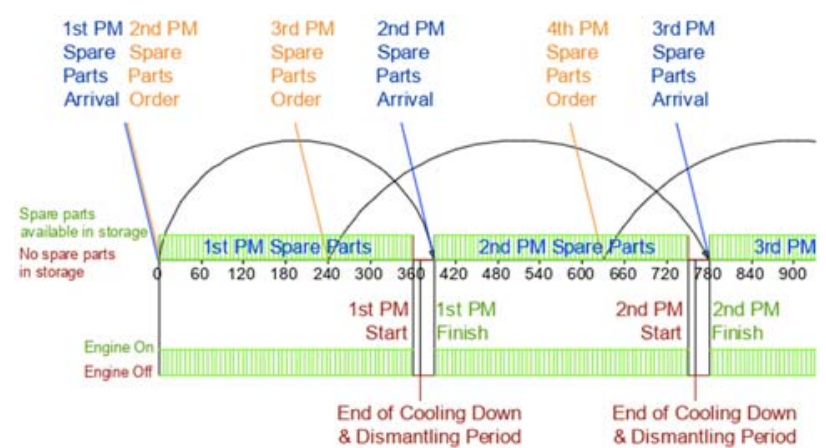

Fig. 1: The basic model of integration between PM and parts, modification from models by W. Wang, 2012 ${ }^{3)}$

In consideration to the engine cooling down and dismantling time factor, an integration model of spare parts and preventive maintenance is proposed. Using this integration model, the potential savings from minimizing storage cost will be uncovered, while on the contrary, the probability of production loss due to spare parts delay will also emerge. Operation duration, PM duration, and spare parts lead time follows the same manner as the basic model. The proposed model is illustrated in Fig. 2.

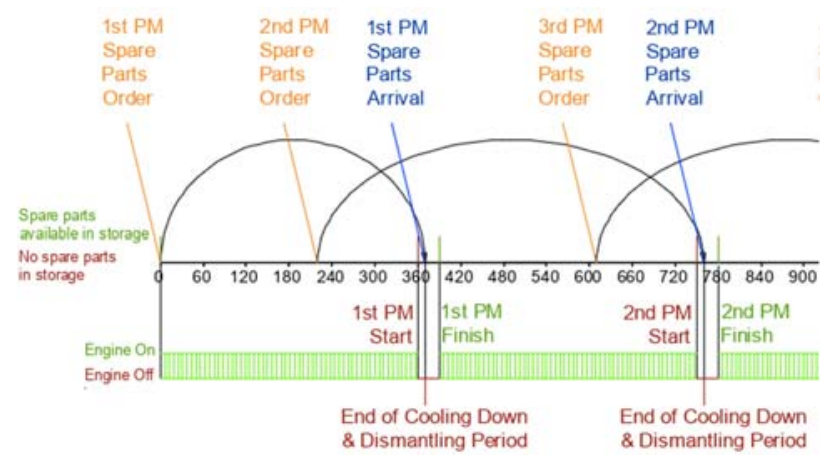

Fig 2: The proposed model of spare parts inventory and preventive maintenance integration

In the proposed model, spare parts arrive at the end of the cooling down and dismantling activities so that unlike the base model, spare parts are not available as long as the gas turbine operates. It is expected that spare parts arrive at the end of the cooling down \& dismantling activities in just-in-time and are immediately ready to be installed.

\section{System Description}

The system consists of components namely engine, spare parts, and PM activities. PM activities are divided into sub-components, namely cooling down \& dismantling and assembling. The condition of the engine is operating or stopping. The condition of spare parts are: not yet ordered, have been ordered, are in shipping, have arrived, are in stock in the warehouse, or are used. Conditions for PM are not ongoing or ongoing. All parts have the same probability of failure and use a block replacement policy where all parts must be completely replaced at PM, regardless of any damage conditions experienced by each spare part. The number of parts ordered is deterministic and the same continues for each order. Ordering parts is done at the same interval for each order and the duration of shipping parts is probabilistic. For each order, spare parts cost also includes the ordering cost and shipping costs to the warehouse. Storage costs are applied daily. PM can only be done if spare parts have arrived or are available in the warehouse. If spare parts are not available, the PM will not be implemented and the new PM can be implemented if spare parts are available. Cooling down \& dismantling duration and assembling duration are probabilistic. It is assumed PM is always successful and decreases the probability of random failure as low as possible so that there is no random failure. The interval between PM is fixed. For each PM event, PM cost are calculated per day.

The machine is always needed to operate throughout $t$ period and there is no condition to stop operation or an order to stop operating other than the implementation of PM. Revenue consisting of payments for costs and profits is obtained for each day of operation. On the day the machine is not operating no income is obtained. The difference between the basic model and the proposed model is that for the proposed model spare parts arrives at the end of the cooling down \& dismantling activities. So unlike the base model, spare parts are not available as long as the gas turbine operates. The DES model version of the base model and the proposed model are shown in Fig. 3.

\section{System Description}

The DES simulation algorithm is as follows:

1. Determine the simulation time.

2. Start the simulation.

3. Determine the value of: spare part order intervals, spare parts lead time, PM interval, service time cooling down \& dismantling duration, and assembling duration.

4. The machine operates as long as the PM has not started, ordering spare parts is carried out, delivery of spare parts is carried out, and spare parts are stored in the warehouse.

5. Decision:

a. 'If spare parts $>0$ and the PM interval have been fulfilled', then move to Step 6.

b. 'If spare parts $=0$ and the interval between PM have been fulfilled' or 'spare parts $>0$ and the interval between PM has not been fulfilled' or 'spare parts $=0$ and the interval between PM has not been fulfilled', then remain in Step 4 . 
6. The machine stops operating and PM is carried out until the duration of cooling down \& dismantling and assembling is complete.

7. If the duration of cooling down \& dismantling and assembling is complete, PM is finished and move to Step 3.

8. Simulation time is reached.

9. Simulation is complete.

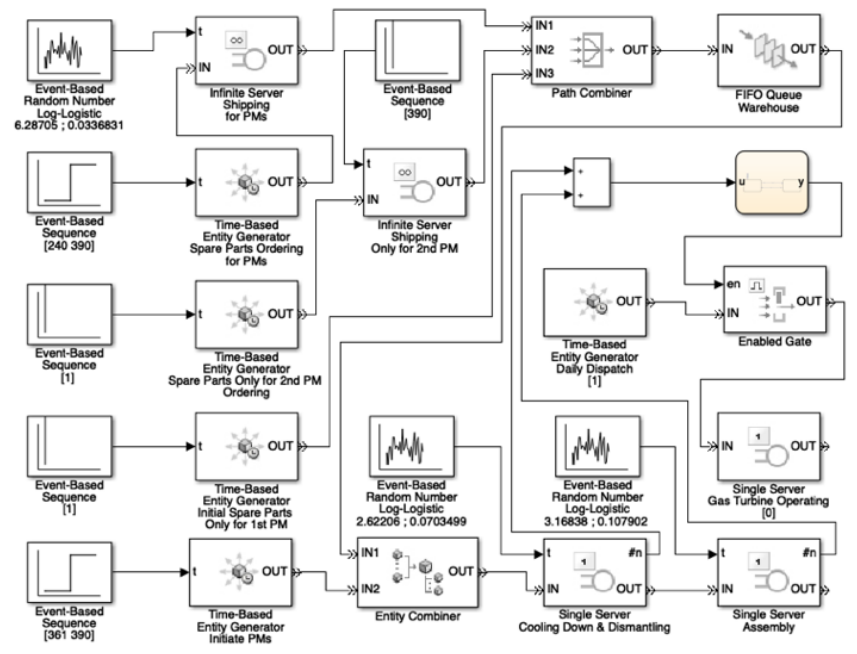

(a)

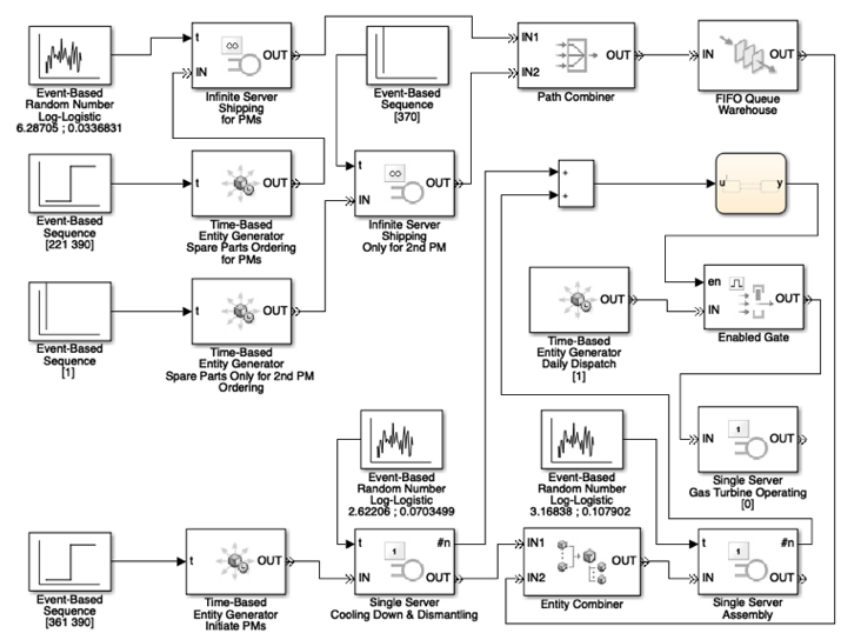

(b)

Fig. 3: The DES model version of the base model (a) and the proposed model (b)

\section{Methodology}

Discrete-event simulation (DES) is an excellent technique for studying and analyzing large-scale systems because they have dynamic and stochastic properties ${ }^{24)}$. By performing a DES simulation, the events that occur in the real world are modeled well by events in the DES simulation. Each event that appears indicates a change in conditions in the system, which is also a representation of real-world conditions. Therefore, the basic model and the proposed model will be converted into the DES model and then simulated. These models will are based on a case study of a power generation company in Indonesia. The DES model will be built based on their historical data.
Maintenance duration history data and duration of parts delivery will be analyzed using the fitting-distribution method to determine the type of data distribution.

The DES model will be verified by an error verification method and random data generated by a random number generator will be verified with the original data using analysis of variance (ANOVA) method and root mean square error (RMSE) method. Then, the DES model will be validated using event validation, entity validation, degenerate test, and extreme value test. The simulation will be carried out in 2 scenarios, namely the first scenario in which the lead time duration of the spare parts is simulated without applying variance reduction and the second scenario where lead time duration of the spare parts by applying variance reduction to represent total implementation of just-in-time. The DES simulation data will then be processed with commercial formulas and commercial data to obtain an economic understanding of the system. Combining simulation result and economic point of view was already done previously in various research fields, including in the field of material engineering in physical and economical perspective $e^{25)}$.

The results of the DES simulation and data processing with formulas and commercial data will be optimized using linear programming method and response surface methodology (RSM). Optimization of the DES simulation results was carried out in order to fully understand the potential of the proposed model with global optima perspective, something which simulation lacks of. The basic and proposed models will be created and simulated using Simevents ${ }^{\circledR}$ and all calculations and optimizations will be carried out using Matlab ${ }^{\circledR}$ by MathWorks, Inc.

\section{Results}

\subsection{Basic Model Simulation Results}

The simulation results for the basic DES model show that over a period of 8000 days, there are 22 times of spare parts ordering, 21 times spare parts delivery, 20 times the duration of spare parts inventory that has been completed in and out of the warehouse, and 20 times of PM events. The duration of shipping parts ranges from 427 and 605 days, the duration of spare parts inventory in the warehouse ranges from 296 and 474 days, the duration of the cooling down \& dismantling process ranges from 9 and 20 days, the duration of the assembling process ranges from 12 and 42 days, the duration of PMs ranges between 27 and 57 days, there was no event of a PM pullback due to delays in the arrival of spare parts, and the number of days of gas turbine production ranging between 7228 and 7277 days. The number of days of PM duration ranges from 723 and 772 days, and the number of days of inventory duration ranges from 7092 and 7640 days. Thus, producing commercially simulated data output into a total cost ranging between 18,210 billion IDR and 18,276 billion IDR, total revenues ranges from IDR 22,987 Billion and IDR 23,144 Billion, so the total profit for 8000 simulation days ranges between IDR 4,778 Billion and 
IDR 4,875 Billion.

\subsection{Proposed Model Simulation by Scenario 1 Results}

The simulation results of the DES model proposed by scenario 1 show that over a period of 8000 days, there are 21 times of spare parts ordering, 20 times spare parts delivery, 20 times the duration of spare parts inventory that has been completed in and out of the warehouse, and 20 times of PM events. The duration of shipping parts ranges from 427 and 605 days, the duration of spare parts inventory in the warehouse ranges from 0 and 116 days, the duration of the cooling down $\&$ dismantling process ranges from 9 and 75 days, the duration of the assembling process ranges between 12 and 42 days, the duration of PMs ranges between 27 and 99 days, the PM pullback occurred due to delays in the arrival of spare parts ranging between 1 and 66 days, and the number of days of gas turbine production ranges from 7041 and 7241 days. The number of days of PM duration ranges between 759 and 959 days, and the number of days of inventory duration ranges between 118 and 534 days. Thus, producing commercially simulated output data into a total cost of between IDR 17,705 Billion and IDR 17,949 Billion, total revenues ranges from IDR 22,392 Billion and IDR 23,030 Billion, so the total profit for 8000 simulation days ranges from IDR 4,687 Billion and 5,081 Billion IDR.

\subsection{Proposed Model Simulation by Scenario 2 Results}

The simulation results of the DES model proposed by scenario 2 show that over a period of 8000 days, there are 21 times of spare parts ordering, 20 times spare parts delivery, 20 times the duration of spare parts inventory that has been completed in and out of the warehouse, and 20 times of PM events. The duration of shipping parts ranges from 530 and 539 days, the duration of spare parts inventory in the warehouse ranges from 0 and 14 days, the duration of the cooling down \& dismantling process ranges from 9 and 20 days, the duration of the assembling process ranges from 12 and 42 days, the duration of PMs ranges between 27 and 57 days, there was no event of a PM pullback due to delays in the arrival of spare parts, and the number of days of gas turbine production ranging between 7228 and 7277 days. The number of days of PM duration ranges from 723 and 772 days, and the number of days of inventory duration ranges between 138 and 172 days. Thus, producing commercially simulated output data into a total cost ranging between IDR 17,918 billion and IDR 17,974 billion, total revenues ranged from IDR 22,987 billion and IDR 23,144 billion, resulting in a total profit of 8,000 simulation days ranging between IDR 5,069 billion and IDR 5,170 billion.

\subsection{Optimization Results from the Proposed Simulation Model Scenario 1 Results with Linear Programming Methods}

The stated goal is to seek maximum profit and the optimization results succeed in obtaining a Number of Days Inventory Duration of 0 days so as to be able to achieve the highest profit value compared to the scenario 1 simulation result, which is 5,427 billion IDR compared to the highest profit the 7th simulation result of 5.081 billion IDR.

\subsection{Optimization Results from the Simulation Model Proposed Scenario 2 Results with Response Surface Methodology (RSM) Method}

The stated goal is to seek maximum profit and the RSM optimization produces the following output:

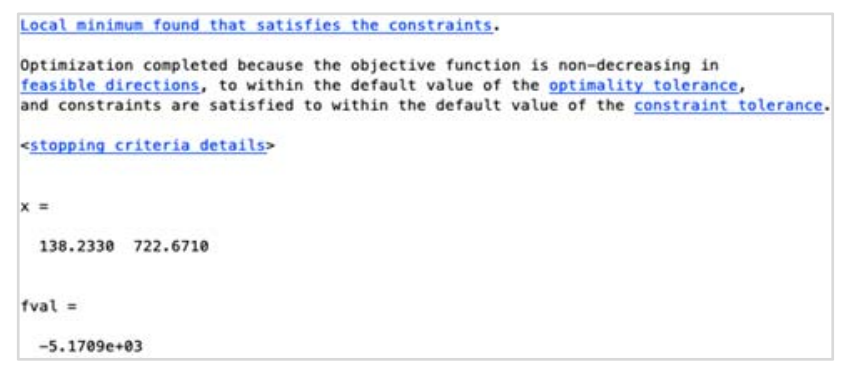

(a)

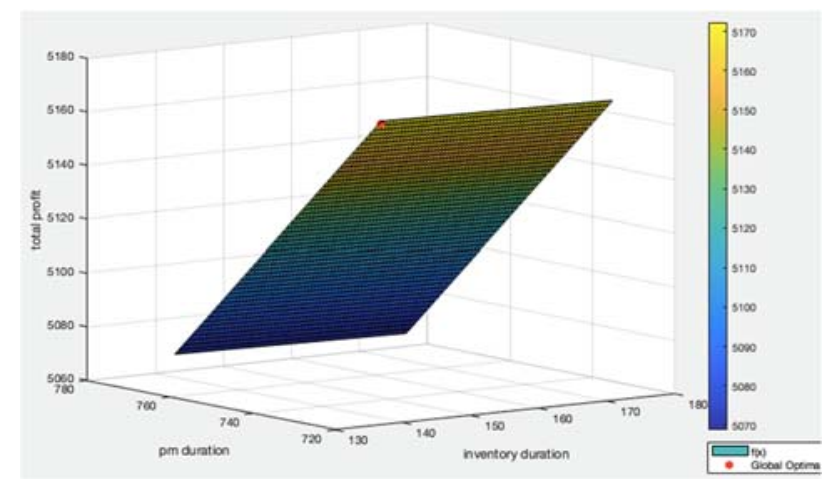

(b)

Fig 4: RSM optimization output: (a) Global optima point in $\mathrm{x}, \mathrm{y}$, and $\mathrm{z}$ coordinates and (b) Graph of global optima point

The stated goal is to find the maximum profit point and the optimization results succeed in obtaining the highest profit value point compared to the simulation result of scenario 2, which is 5.171 billion IDR at the point of $(138,233,722,671)$ compared to the highest profit of the fifth simulation result is obtained, namely 5.170 billion IDR at the point of $(160,761,722,671)$.

\section{Conclusion}

It can be concluded that:

1. The basic model simulation results in a high duration of spare parts inventory which results in high storage costs. The simulation results on the model proposed scenario 1 resulted in a much lower duration of spare parts inventory than the base model but there was a large variance in the duration of delivery of parts which often caused the duration of cooling down \& 
dismantling to be extend so that the assembling could not be done before the spare parts arrived increasing duration of PM. Simulation of the model proposed scenario 2 produces a lower inventory duration than scenario 1 and also with a low variance so that it does not cause the duration of cooling down \& dismantling delayed and assembling to be carried out immediately.

2. The results of linear programming optimization performed on the simulation results on the model proposed scenario 1 shows the potential to obtain the duration of spare parts inventory which reaches 0 days if the duration of parts delivery, cooling down \& dismantling, and assembling is always on time according to the contract and recommendations on maintenance guidelines. And, the results of RSM optimization performed on the simulation results on the model proposed in scenario 2 show that based on the simulation results it is predicted that there is still a potential for a decrease in the number of days of spare parts duration and the number of days of PM to achieve higher total profits.

3. Spare parts and preventive maintenance integration models have been obtained by considering engine cooling down and dismantling factors whose arrival time of parts is set after completion of engine cooling down and dismantling to reduce the duration of spare parts inventory from a maximum of 474 days to a maximum of 14 day.

4. From the case study of PT Indonesia Power - PLTGU Grati, East Java, we obtained a decrease in the duration of spare parts inventory, which increased the company's total profit from the initial maximum to reach 4.875 billion IDR to 5.171 billion IDR.

5. In addition to benefiting from the implementation of the proposed model, namely decreasing the cost of storing spare parts and increasing the company's total profits, it also obtain other benefits, namely by decreasing storage costs, the company's cash increases. Some amount of cash from a number of lowered storage costs can improve the company's cash level so that it is more liquid to be able to use other needs, for example other operational needs, investments, debt payments, dividend payments, or stored for future corporate growth opportunities.

\section{Future Research}

In this study, although the duration of shipping parts, cooling down and dismantling, and the duration of assembling are probabilistic, the order time and interval between PMs are deterministic and fixed. In fact, the time to place an order and the interval between PMs is always different and varied.

For future research, the ordering time and intervals between PMs can be made probabilistic to give closer research results to the actual conditions.

\section{References}

1) T. Sato, "How is a sustainable society established?: a case study of cities in japan and germany how is a sustainable society established? a case study of cities in japan and germany," Evergr. Jt. J. Nov. Carbon Resour. Sci. Green Asia Strateg., 3 (2) $25-$ 35 (2016).

2) T. Gallagher, M.D. Mitchke, and M.C. Rogers, "Profiting from spare parts," McKinsey Quarterly, Web Exclus., (Exhibit 2) (2005).

3) W. Wang, "A stochastic model for joint spare parts inventory and planned maintenance optimisation," Eur. J. Oper. Res., 216 (1) 127-139 (2012). doi:10.1016/j.ejor.2011.07.031.

4) A.A. Prihandoyo, T.Y. Zagloel, and R. Ardi, "Integration cost model of predictive maintenance and stock inventory with consideration of multiechelon logistic," Asia Pacific Conf. Res. Ind. Syst. Eng., 65-69 (2018).

5) M. Bošnjaković, "Multicriteria inventory model for spare parts,” Tech. Gaz., 17 499-504 (2010).

6) A.H. Elwany, and N.Z. Gebraeel, "Sensor-driven prognostic models for equipment replacement and spare parts inventory," IIE Trans. (Institute Ind. Eng., 40 (7) 629-639 (2008). doi:10.1080/07408170701730818.

7) F. Zahedi-hosseini, and P. Scarf, "Joint maintenanceinventory optimisation of parallel production systems," J. Manuf. Syst. 48 73-86 Contents, 48 (January) 73-86 (2018).

8) M.A. Ilgin, and S. Tunali, "Joint optimization of spare parts inventory and maintenance policies using genetic algorithms," Int. J. Adv. Manuf. Technol., (2007). doi:10.1007/s00170-006-0618-z.

9) W. Wang, "A stochastic model for joint spare parts inventory and planned maintenance optimisation," Eur. J. Oper. Res., (2012). doi:10.1016/j.ejor.2011.07.031.

10) A. Alrabghi, A. Tiwari, and A. Alabdulkarim, "Simulation based optimization of joint maintenance and inventory for multi-components manufacturing systems," Proc. 2013 Winter Simul. Conf., 11091119 (2013).

11) E.T.S. Bjarnason, S. Taghipour, and D. Banjevic, "Joint optimal inspection and inventory for a k-outof-n system," Reliab. Eng. Syst. Saf., 131 203-215 (2014). doi:10.1016/j.ress.2014.06.018.

12) N.K. Samal, and D.K. Pratihar, "Joint optimization of preventive maintenance and spare parts inventory using genetic algorithms and particle swarm optimization algorithm," Int. J. Syst. Assur. Eng. Manag., 6 (3) 248-258 (2015). doi:10.1007/s13198015-0349-3.

13) B. Kader, D. Sofiene, R. Nidhal, and E. Walid, "Ecological and joint optimization of preventive maintenance and spare parts inventories for an optimal production plan," IFAC-PapersOnLine, 28 (3) 2139-2144 (2015). doi:10.1016/j.ifacol.2015.06.405. 
14) Y. Jiang, M. Chen, and D. Zhou, "Joint optimization of preventive maintenance and inventory policies for multi-unit systems subject to deteriorating spare part inventory," J. Manuf. Syst., 35 191-205 (2015). doi:10.1016/j.jmsy.2015.01.002.

15) Y. Wang, H. Gu, J. Zhao, and Z. Cheng, "Modeling on spare parts inventory control under condition based maintenance strategy," J. Shanghai Jiaotong Univ., 21 (5) 600-604 (2016). doi:10.1007/s12204016-1769-1.

16) A. Mjirda, R. Benmansour, H. Allaoui, and G. Goncalves, "On the joint optimization of the periodic preventive maintenance and the spare parts inventory problem," IFAC-PapersOnLine, 49 (12) 881-885 (2016). doi:10.1016/j.ifacol.2016.07.886.

17) M.C.A. Olde Keizer, R.H. Teunter, and J. Veldman, "Joint condition-based maintenance and inventory optimization for systems with multiple components,' Eur. J. Oper. Res., 257 (1) 209-222 (2017). doi:10.1016/j.ejor.2016.07.047.

18) K.A. Nguyen, P. Do, and A. Grall, "Joint predictive maintenance and inventory strategy for multicomponent systems using birnbaum's structural importance," Reliab. Eng. Syst. Saf., 168 (May) 249261 (2017). doi:10.1016/j.ress.2017.05.034.

19) C.M. La Fata, and G. Passannanti, "A simulated annealing-based approach for the joint optimization of production/inventory and preventive maintenance policies," Int. J. Adv. Manuf. Technol., (2017). doi:10.1007/s00170-017-0053-3.

20) A. Bousdekis, N. Papageorgiou, B. Magoutas, and D. Apostolou, "A proactive event-driven decision model for joint equipment predictive maintenance and spare parts inventory optimization," Procedia CIRP, 59 (TESConf 2016) 184-189 (2017). doi:10.1016/j.procir.2016.09.015.

21) F. Zahedi-Hosseini, P. Scarf, and A. Syntetos, "Joint optimisation of inspection maintenance and spare parts provisioning: a comparative study of inventory policies using simulation and survey data," Reliab. Eng. Syst. Saf., 168 (March) 306-316 (2017). doi:10.1016/j.ress.2017.03.007.

22) G.Q. Cheng, B.H. Zhou, and L. Li, "Integrated production, quality control and condition-based maintenance for imperfect production systems," Reliab. Eng. Syst. Saf., 175 (September 2017) 251264 (2018). doi:10.1016/j.ress.2018.03.025.

23) N.J. Olckers, "An Evaluation of Just-in-Time Principles as Part of The Logistics Chain in an Engineering Business," Rand Afrikaans University, 1998.

24) L.A. Riley, "Discrete-Event Simulation Optimization: A Review of Past Approaches and Propositions for Future Direction," in: Summer Comput. Simul. Conf., 2013.

25) C.K.P. Azimil Gani Alam, Nasruddin, Andy Tirta, "Building beneficial roof insulation in vertical housing : physical and economical selection method," Evergr. Jt. J. Nov. Carbon Resour. Sci. Green Asia
Strateg., 6 (2) 124-133 (2019). 